\title{
Származási régiók növényföldrajzi felülvizsgálata honos fajok magjainak restaurációs célú felhasználására
}

\author{
Török Katalin ${ }^{1}$, David Cevallos ${ }^{1,2}$ és Bede-Fazekas Ákos ${ }^{1,3}$ \\ ${ }^{1}$ Ökológiai Kutatóközpont, Ökológiai és Botanikai Intézet, \\ 2163 Vácrátót, Alkotmány u. 2-4. \\ ${ }^{2}$ Eötvös Loránd Tudományegyetem, Növényrendszertani, Ökológiai és Elméleti Biológiai \\ Tanszék, 1117 Budapest, Pázmány Péter stny. 1/C \\ ${ }^{3}$ Ökológiai Kutatóközpont, GINOP Fenntartható Ökoszisztémák Csoport, \\ 8237 Tihany, Klebelsberg K. и. 3. \\ E-mail:torok.katalin@ecolres.hu
}

\begin{abstract}
Összefoglaló: A biodiverzitás pusztulása miatt az ökológiai restauráció a legmagasabb szintű politikai döntéshozás homlokterébe került. A restauráció területének növelése érdekében a honos fajok magjainak nagyobb mértékủ felhasználására van szükség. A lokálisan adaptálódott populációból származó magok használatát rendelet szabályozza, melyet hazánkban a közigazgatási régiók határaihoz igazítottak. Jelen dolgozatban magtranszferzónák kijelölésére teszünk kísérletet flóra-, vegetáció- és tájszintü régiós térképek, valamint többrétegü potenciálisvegetáció-modell felhasználásával. Új módszert fejlesztettünk a zónalehatárolás megbízhatóságának elemzésére. A 4-9 egységből álló magtranszferzóna-rendszerek megbízhatósági elemzésének eredménye alapján a négy vagy a hét zónából álló rendszer tünik alkalmasabbnak. További finomhangolás és tesztelések után a jelenleg érvényben lévő rendelet módosítandó.
\end{abstract}

Kulcsszavak: növényföldrajz, restaurációs ökológia, helyi adaptálódás, honos fajok magjainak termesztése, többrétegü potenciálisvegetáció-becslés, magtranszfer-szabályozás

\section{Bevezetés}

Azzal, hogy az ENSZ a 2020-2030 közötti időszakot az ökoszisztéma-restauráció évtizedének nevezte ki, az ökológiai restauráció a legmagasabb szintü politikai döntéshozás homlokterébe került (http1). Ezt a döntést olyan aggasztó jelentések indokolják, melyek az élővilág rohamos pusztulásáról, és ennek az emberi életminőségre gyakorolt káros hatásáról számolnak be (IPBES 2019). Az ökológiai restauráció közérdek, ezért térbeli kiterjedését és a beavatkozások intenzitását növelni szükséges (Aronson \& Alexander 2013). Ezen célok csak a honos fajok 
szaporítóanyagának, elsősorban magjainak nagyobb mértékü felhasználásával érhetők el (Massatti et al. 2020, Pedrini \& Dixon 2020). A „restaurációs fajkínálat”, vagyis a piacon hozzáférhető fajok magkészlete a restaurációs projektek kritikus pontját jelenthetik (Ladouceur et al. 2018). Hazánkban is van igény szaporítóanyagra pl. nemzeti parki restaurációs tevékenységekhez (Valkó et al. 2018, Török et al. 2019). Honos fajok restaurációs fajkínálata akkor fogja biztosítani a restaurált területek genetikai diverzitásának fenntartását, ha a vetőmagokat a fajok elterjedését, populációit és azok változatosságát is figyelembe vevő, szisztematikusan begyüjtött forrásokból biztosítjuk (Hoban \& Schlarbaum 2014).

A magok vetésével történő restauráció során fontos szempont, hogy lokálisan adaptálódott populációból származó magot használjunk, és elkerüljük a genetikai szennyezést (Bischoff et al. 2006, 2010). Nagy számú, a fajok genetikai változatosságát leíró adat hiányában a szakirodalomban még vita folyik arról, hogy milyen mértékben szükséges a lokális magokra támaszkodni, de általános vélemény, hogy a telepítéseket származás szerint szabályozni szükséges (Gibson \& Nelson 2017, Giencke et al. 2018). A telepítések szabályozására ún. magtranszferzónákat (MTZ-ket), vagy származási zónákat hozhatunk létre, melyeken belül a fajok alacsony kipusztulási kockázattal telepíthetők át (Bucharova et al. 2017, Breed et al. 2018), és minimális a biodiverzitás-veszteség a helyi populációk esetleges kiszorításával (Malaval et al. 2010). Az MTZ-k kijelölését egy európai bizottsági irányelv írja elő (EC 2010), melyet Magyarországon az adminisztrációs zónák (NUTS2) átvételével oldottak meg (VM 2012). Mivel az MTZ-k azok a területek, melyeken belül a fajok, ill. magkeverékek gyüjtése, szaporítása, telepítése engedélyezhető, ezért átgondolatlan, szakmai megalapozást nélkülöző kijelölésük esetén a restaurációs beavatkozások egy részét indokolatlanul megnehezítenék. Más országokban a MTZ-k kijelölésének alapja valamilyen biogeográfiai, vegetációs, vagy ökorégió (Prasse et al. 2010, FCBN 2014, Krautzer et al. 2018). Ezen megközelítés helyességét átültetéses és genetikai kísérletekkel alá is támasztották (Bucharova et al. 2017, Durka et al. 2017, Gibson \& Nelson 2017). Európában a vegetáció leírása és térképezése hosszú múltra tekint vissza (Mucina et al. 2016), így jó alapot adhat a biogeográfiai megközelítésủ származási zónák, vagy MTZ-k kialakításához. Magyarország területére flóra-, vegetáció- és tájszintủ régiókat különítettek el (Hajdú-Moharos \& Hevesi 2002, Molnár et al. 2008, Kocsis \& Schweitzer 2011), melyek a származási zónák tervezésének alapját adhatják. A régióhatárokat nagymértékben befolyásolták szakértői döntések és a helyi vegetáció ismerete, ám léptékük területenként eltérö lehet. Ez a torzítás csökkenthetö, ha a fenti térképek mellett finom felbontású, terepi megfigyelési adatokra támaszkodó nagy adatbázisokat és környezeti változókat is figyelembe veszünk. Ilyen adatbázis lehet a potenciális természetes vegetáció modellje, mely a már elpusztult 
élőhelyek területére is képes a vegetációtípusok előfordulásának valószínüségét megadni.

Az új fejlesztésü, Magyarországra kidolgozott többrétegủ potenciális természetes vegetáció (MPNV) modell (http2) egy adott pontra több élőhelytípus valószínűségére is becslést ad (Somodi et al. 2017). A modell a természetközeli élőhelyek megfigyelt előfordulása mellett környezeti háttérváltozókat vesz figyelembe, nevezetesen az éghajlatot, a hidrológiai és talajjellemzőket, valamint a domborzati viszonyokat. A modell felbontása lehetővé teszi, hogy a biogeográfiai térképek régióinak összevonásával, a hasonló potenciális élőhelytípus-összetételü szomszédos egységek összesítése alapján operatív méretủ és mennyiségü MTZ-t hozzunk létre. Ezt a megközelítést korábban már sikeresen alkalmaztuk az így nyert zónák és a jelenleg hatályos adminisztratív régiók megbízhatóságának öszszevetésére (Cevallos et al. 2020). Az alkalmassági tesztelés során azonban a hét adminisztratív régióval értelemszerúen csak azonos számú MTZ-t hasonlíthattunk össze. Belátható, hogy ez az önkényes zónaszám nem feltétlenül a legmegfelelőbb beosztás a magok származási és telepítési zónáinak meghatározására. Az említett korábbi munka módszereit és eredményeit itt is röviden összefoglaljuk az érthetőség érdekében.

Dolgozatunk célja következő lépésként megvizsgálni, hogy az MPNV modell felhasználásával mennyi és milyen geometriájú területek határolhatók le, továbbá a különböző zónaszám esetén az eredmények megbízhatósága hogyan alakul. A megbízhatóság tekintetében a geometriától való függés elemzését végezzük el, hiszen joggal feltételezhető, hogy a zónák képzéséhez felhasznált kiindulási geometriák nagyban meghatározzák a kapott eredményt. Az eredmények alapján javaslatot teszünk a szabályozás módosítására, illetve a megbízhatóság geometriafüggéstől eltérő szempontú értékelésére is.

\section{Anyag és módszer}

Kitüzött céljaink megvalósításához az alábbi lépéseket végeztük el, melyeket e fejezetben röviden ismertetünk, a részletes leírásuk pedig Cevallos és munkatársai (2020) munkájában olvasható:

- $\quad$ alaptérkép létrehozása;

- $\quad$ alaptérkép feltöltése az MTZ-k létrehozásához szükséges vegetációs adatokkal;

- különböző számú zónából álló MTZ-k létrehozása klaszterezéssel;

- semleges geometriájú referenciaklaszterek létrehozása, és az MTZ-k kiindulási geometriától való függetlenségének értékelése e referenciaklaszterekkel való összevetés segítségével. 
Az alaptérkép geometriájának (értsd: poligonjainak, foltjainak) létrehozásához a következő három térképet használtuk fel: Magyarország florisztikainövényföldrajzi beosztása (Molnár et al. 2018), Magyarország vegetációs tájbeosztása (Molnár et al. 2008) és a kárpát-pannon természeti tájbeosztás magyarországi kivágata (Hajdú-Moharos \& Hevesi 2002). Az első említett térképet digitális formában Király Gergelytől kaptuk meg, a vegetációs tájbeosztás szabadon elérhető, a kárpát-pannon tájbeosztást a szerzők digitalizálták. A 136 foltot tartalmazó alaptérképet e három térkép metszeteként állítottuk elő kellő geometriai egyszerüsítés után.

Az alaptérkép geometriai vázát ezután vegetációs adatokkal töltöttük fel. Ebben Somodi és munkatársai (2017) többrétegü potenciálisvegetáció-becslésére támaszkodtunk, amely 39 élőhely (Bölöni et al. 2011) előfordulási valószínüségét jelzi ötelemü ordinális skálán, teljes Magyarországra, 35 ha-os hatszögrácsban. A következő lépéshez az élőhely-előfordulási valószínűségek alapján kiszámoltuk a foltok vegetációs távolságát.

A klaszterezéshez olyan algoritmust választottunk, amely képes térben összefüggő MTZ-ket kialakítani, hiszen szigetszerüen széteső foltcsoportok MTZ-ként való értelmezése, és az erre alapozott szabályozás nehézkes lenne. Ilyen algoritmus a SKATER (Assunção et al. 2006), amely előzetesen rögzített számú klasztert hoz létre. Kutatásunkban a klaszterek számát négy és kilenc között változtattuk, így összesen hat, egymástól független MTZ-térképet hoztunk létre.

A zónafelosztások megbízhatóságának (Dong et al. 2015, Retchless \& Brewer 2016) számszerüsítéséhez 4-9 referenciaklasztert képeztünk a fentiekhez hasonló módon, de ezúttal semleges geometriából kiindulva. Ilyen semleges, az alaptérképünktől teljesen független kiindulási alapot biztosít Magyarország Élőhelyeinek Térképi Adatbázisának (MÉTA; Molnár et al. 2007) 2834 - közel négyzet alakú - kvadrátja, melyek mérete megközelítőleg $35 \mathrm{~km}^{2}$. A kvadrátok elrendezése teljesen szisztematikus, nem támaszkodik vegetációs vagy közigazgatási határokra. A kvadrátok klaszterei ezért jó közelítéssel a kiindulási geometriától független, csak a potenciálisvegetáció-becslésre támaszkodó MTZ-kként értékelhetők. Adott klaszterszám esetén az alaptérképből előállított MTZ-k és a referenciaklaszterek hasonlóságát, átfedését számszerúsítettük, ezzel becsülve, hogy az MTZ-k menynyire függetlenek a geometriától, amely a megbízhatóság egyik jellemzőjeként értékelhető. Ehhez előzetesen az MTZ-ket a referenciaklaszterekhez kapcsoltuk, és az összekapcsolt klaszterek területi átfedését (,egyetértését”) számítottuk és jelenítettük meg a kvadrátok felbontásában.

Az elemzéseket ESRI ArcGIS 10.2 térinformatikai és R statisztikai szoftverrel (R Core Team 2018) végeztük, a következö R-csomagok felhasználásával: „sf” (Pebesma 2018a), ,gtools” (Warnes et al. 2018), „lwgeom” (Pebesma 2018b) és „tidyverse” (Wickham 2017). 


\section{Eredmények}

A klaszterezéssel nyert MTZ-térképeket különböző zónaszámok esetén az 1. ábra első oszlopa mutatja be. Mindegyik eredménytérképen a Dunántúl és az Alföld nagy része viszonylag egységes, és általános a Balaton-felvidék és a Bakony elkülönülése, már a négy zónás térképtől kezdve. A Kiskunság már öt zóna esetén is elválik, majd a zónák számának növekedésével a Pilis-Visegrádi-hegység, a Nyírség és az Örség területe jelenik meg önálló egységként.

Az alaptérkép geometriája nélkül készült referenciaklaszterek az 1. ábra második oszlopában láthatók. Feltünő különbség a MTZ-térképekhez képest a Balatonfelvidék/Bakony elkülönülésének hiánya. Az Északi-középhegység jobban tagolódik, a Kiskunság csak a hét zónás változattól kezdve válik el, majd a Dunántúl nyugati és keleti részre különül, így a két változat közötti különbség jelentős. Az egyetértési térképek (1. ábra 3. oszlop) adják a megbízhatósági becslést, ahol a zöld szín mutatja az egyezést az MTZ- és a referenciaklaszterek között, melyek területarányát a 2. ábrán tüntettük fel. Az egyezés mértéke az elkülönített egységek számának növekedésével egyenletesen csökken, kivéve a hét zónás esetet, amely kiemelkedően jó egyezést mutat.

\section{Diszkusszió}

Jelen cikkben kísérletet tettünk arra, hogy növényföldrajzi zónák és többrétegü potenciálisvegetáció-becslés alapján az ökológiai restauráció területi szabályozására alkalmas régiókat határoljunk le. A honos növényfajok genetikai változatosságáról keveset tudunk, ami jelentős nehézséget okoz más országokban is a restauráció során szükséges magbeszerzések szabályozásában (Bucharova et al. 2019, León-Lobos et al. 2020). A vegetáció és a környezeti állapotváltozók együttes használatával helyettesíthetjük a faj alapú ismeretek hiányát, így megközelítésünk alkalmas lehet sok növényfaj számára megfelelő MTZ-k kijelölésére (Prasse et al. 2010, Krautzer et al. 2018). Korábban kényszerüen hét zóna lehatárolásával teszteltük a jelenleg érvényben lévő hét közigazgatási régió (NUTS2) és a módszerünkkel kapott zónák megbízhatóságát független geometriájú referenciaklaszterek segítségével (Cevallos et al. 2020). Hét MTZ esetén az alaptérkép klaszterei függetlenebbek a geometriától (76\%-os egyezés), mint a NUTS2 közigazgatási régiók (42\%), így ebböl a szempontból a NUTS2 régiók kevésbé alkalmasak MTZ-k kijelölésére, mint az alaptérkép klaszterei (Cevallos et al. 2020). Ebben az új vizsgálatban ez a kényszer nem korlátozta az elemzést, így 4-9 számú zóna lehatárolásának eredményeit adhattuk meg. 
Magtranszferzónák (klaszterezett alaptérkép)
Referenciaklaszterek (klaszterezett MÉTA-kvadrátok)
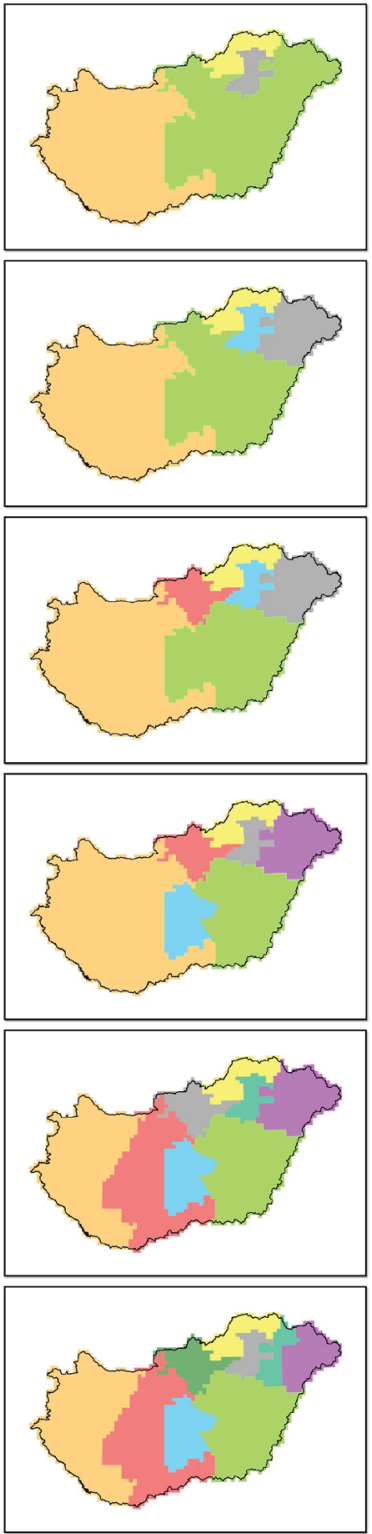

Egyetértési térképek (megbízhatósági becslés)
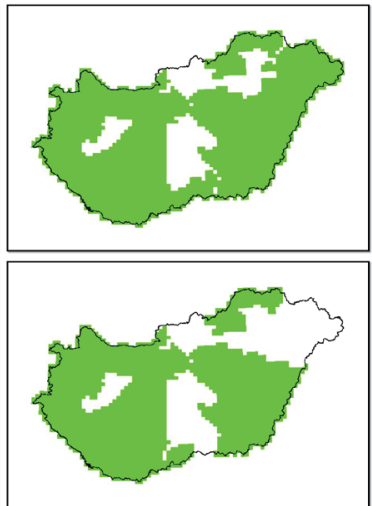

6
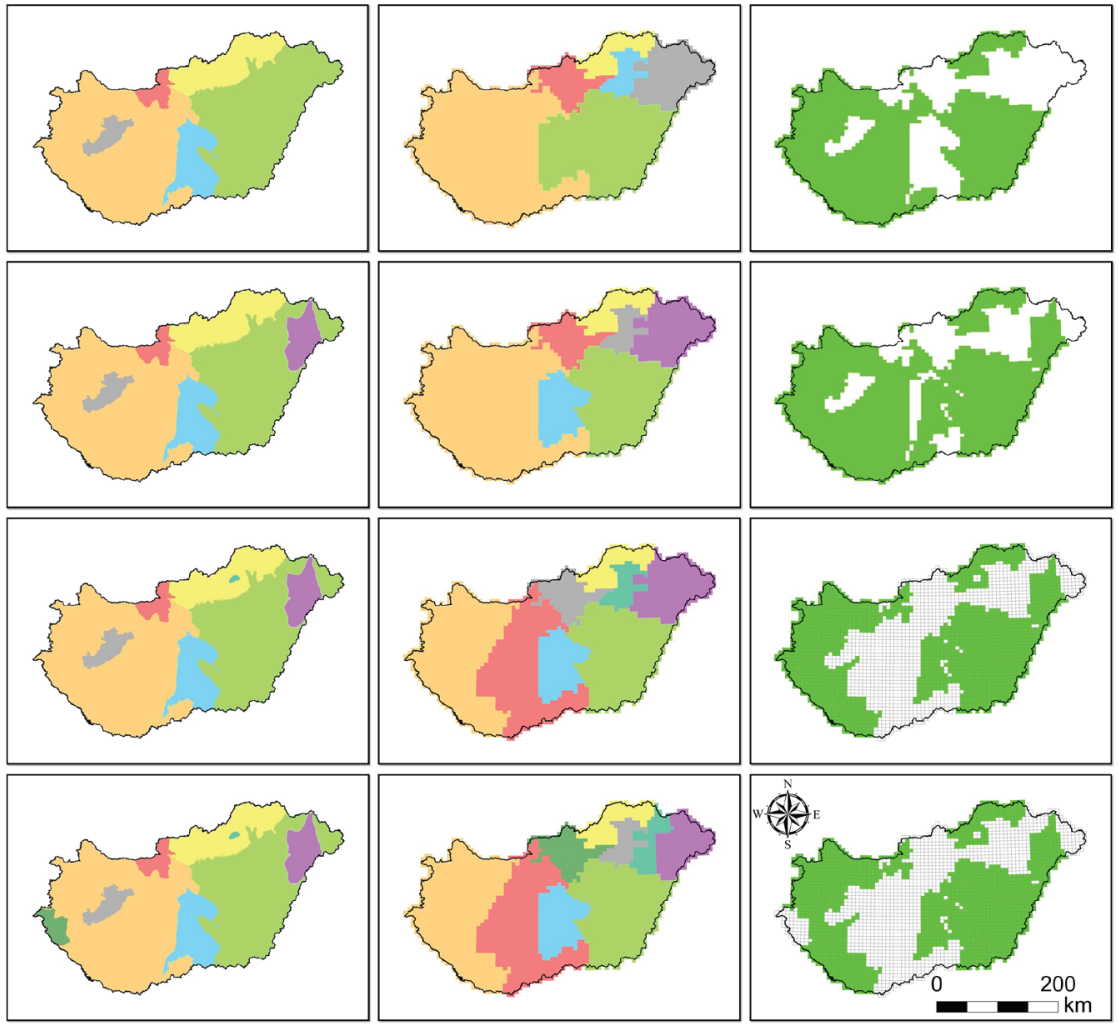

1. ábra: Magtranszferzóna-elemzések eredményei 4-9 klaszterre. Az első oszlopban az alaptérkép geometriájára alapozott klaszterezés eredményei találhatók; a második oszlopban a független geometriájú MÉTA-kvadrátok klasztereredményei; míg a harmadik oszlopban a két típusú klaszterezés közötti egyetértési térképek láthatók (zöld színnel jelöltük azon kvadrátokat, ahol a két térkép megegyezik). 


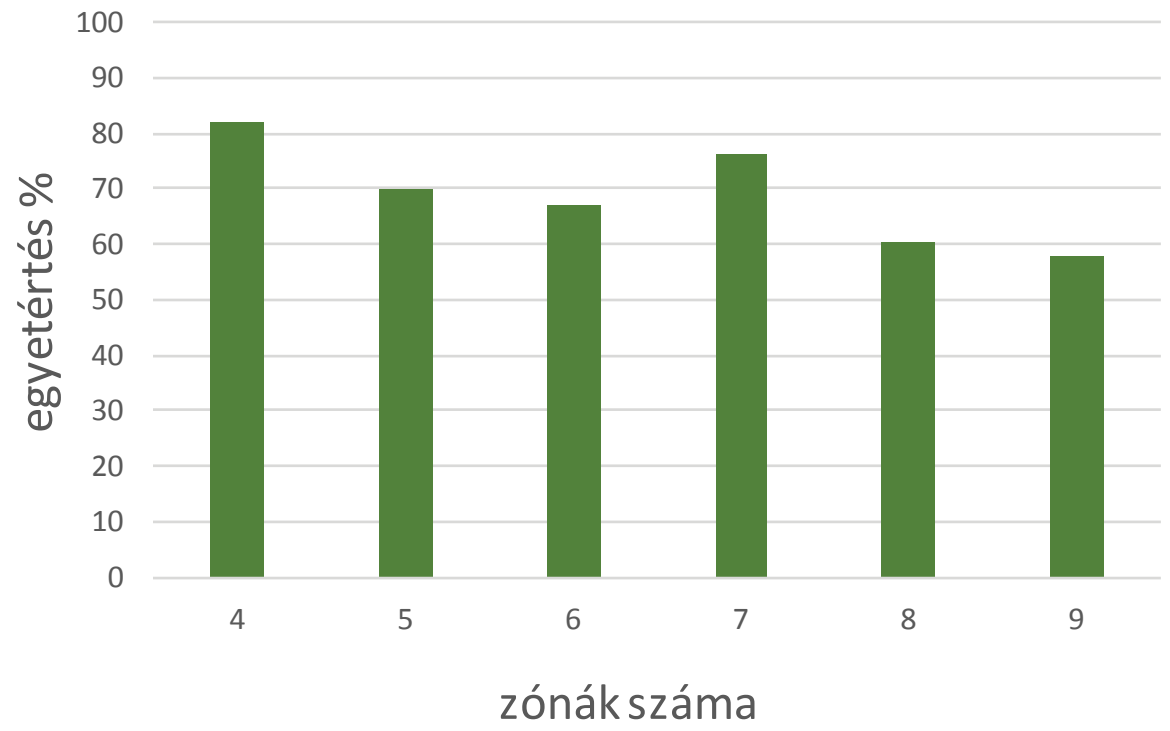

2. ábra: Az egyezések aránya (\%) Magyarország területén belül a 4-9 zónára vonatkozó eredmények alapján.

A megbízhatósági eredmények alapján a négy vagy a hét zóna tủnik alkalmasabbnak restaurációs célú származási zónának. Mivel a klaszterszám növelésével részletezettebb, a célnak mindinkább megfelelő eredményt kapunk, ugyanakkor a megbízhatóság általában csökken, a hét zónás változat megfelelő kompromiszszumnak tünik. A hét zóna esetén a Kiskunság mindkét térképen való elkülönülése adja a nagyobb egyezést. Ennek a változatnak a létjogosultságát faj szintủ elemzésekkel kellene a későbbiekben alátámasztani.

A megbízhatósági elemzés, amelyet a MTZ-kre elvégeztünk, a zónák megbízhatóságának csak egy vetületéről, nevezetesen a geometriától való függetlenségükről árul el információt. Legfontosabb megállapításunk, hogy a klaszterek számát négytől kilencig növelve a kiindulási geometria mind nagyobb szerepet játszik a MTZ-k kialakításában. Kivételt ez alól csupán a hét klaszterből álló felosztás jelent, amely az öt és a hat klaszterből álló felosztásokhoz képest a geometriától függetlenebbnek bizonyult. Nem kívánunk jelen kutatás keretében egyértelmú javaslatot tenni a zónák számára, valamint a végleges lehatárolásukhoz is további vizsgálatokat, szakértői egyeztetéseket tartunk szükségesnek. E megállapításainkon túllépni, és az eredmények megbízhatóságát más szempontokból is körbejárni célzott, pl. csíráztatási, genetikai kísérletekkel, vagy faji jellegek elemzésével lehet. A megbízhatósági elemzés gyakorlati haszna a számszerü összehasonlításban rejlik, mely a jogszabály-módosítások esetén a döntéshozást megkönnyítheti. 
Fontosnak tartjuk a zónabeosztás szabályozásának megváltoztatását, azonban a végleges javaslathoz szükséges a terepet ismerő, élőhelyrekonstrukciós beavatkozásokban gyakorlott szakértők véleményének figyelembevétele. A jelenlegi szabályozás alapját képező EU irányelv tekintetében is módosításokra lenne szükség, mivel pl. a csíraképességi követelmények irreálisak, honos fajokra nem teljesíthetők (Ladouceur et al. 2017). Miután sor kerül annak módosítására, majd a hazai szabályozásba való átültetésére, akkor következhet a zónahatárok módosítása is. A jelen munkában készített összehasonlítások és számszerü becslések alátámaszthatják a szabályozás módosításának szükségességét.

Köszönetnyilvánitás - A szerzők szeretnének ezúton köszönetüket kifejezni Király Gergelynek (Soproni Egyetem), aki a digitalizált florisztikai-növényföldrajzi tájbeosztást rendelkezésükre bocsátotta. Csiky János alapos, ösztönöző szakmai bírálata segítette a kézirat pontosítását, köszönjük. A kutatás megvalósítását a KEHOP-4.3.0VEKOP-15-2016-00001, GINOP-2.3.2-15-2016-00019 és Stipendium Hungaricum programok támogatták.

\section{Irodalomjegyzék}

Aronson, J. \& Alexander, S. (2013): Ecosystem restoration is now a global priority; time to roll up our sleeves. - Restor. Ecol. 21: 293-296. https://doi.org/10.1111/rec.12011

Assunção, R. M., Neves, M. C., Câmara, G. \& Da Costa Freitas, C. (2006): Efficient regionalization techniques for socio-economic geographical units using minimum spanning trees. - Int. J. Geogr. Inf. Sci. 20: 797-811. https://doi.org/10.1080/13658810600665111

Bischoff, A., Steinger, T. \& Müller-Schärer, H. (2010): The importance of plant provenance and genotypic diversity of seed material used for ecological restoration. - Restor. Ecol. 18: 338-348. https://doi.org/10.1111/j.1526-100X.2008.00454.x

Bischoff, A., Vonlanthen, B., Steinger, T. \& Müller-Schärer, H. (2006): Seed provenance matters effects on germination of four plant species used for ecological restoration. - Basic. Appl. Ecol. 7: 347-359. https://doi.org/10.1016/j.baae.2005.07.009

Bölöni, J., Molnár, Zs. \& Kun, A. (szerk.) (2011): Magyarország élőhelyei. A hazai vegetációtípusok leírása és határozója. ÁNÉR 2011. - MTA ÖBKI, Vácrátót, 439 p.

Breed, M., Harrison, P., Bischoff, A., Durruty, P., Gellie, N., Gonzales, E. K., Havens, K., Karmann, M., Kilkenny, F., Krauss, S. L., Lowe, A. J., Marques, P., Nevill, P. G., Vitt, P. L. \& Bucharova, A. (2018): Priority actions to improve provenance decision-making. - Bioscience 68: 510-516. https://doi.org/10.1093/biosci/biy050

Bucharova, A., Bossdorf, O., Hölzel, N., Kollmann, J., Prasse, R. \& Durka, W. (2019): Mix and match: regional admixture provenancing strikes a balance among different seed-sourcing strategies for ecological restoration. - Conserv. Genet. 20: 7-17. https://doi.org/10.1007/s10592-018$\underline{1067-6}$

Bucharova, A., Michalski, S., Hermann, J. M., Heveling, K., Durka, W., Hölzel, N., Kollmann, J. \& Bossdorf, O. (2017): Genetic differentiation and regional adaptation among seed origins used for grassland restoration: Lessons from a multi-species transplant experiment. - J. Appl. Ecol. 54: 127-136. https://doi.org/ 10.1111/1365-2664.12645 
Cevallos, D., Bede-Fazekas, Á., Tanács, E., Szitár, K., Halassy, M., Kövendi-Jakó, A. \& Török, K. (2020): Seed transfer zones based on environmental variables better reflect variability in vegetation than administrative units: evidence from Hungary. - Restor. Ecol. 28: 911-918. https://doi. org/10.1111/rec.13150

Dong, M., Bryan, B. A., Connor, J. D., Nolan, M. \& Gao, L. (2015): Land use mapping error introduces strongly-localised, scale-dependent uncertainty into land use and ecosystem services modelling. - Ecosyst. Serv. 15: 63-74. https://doi.org/10.1016/j.ecoser.2015.07.006

Durka, W., Michalski, S. G., Berendzen, K. W., Bossdorf, O., Bucharova, A., Hermann, J. M., Hölzel, N. \& Kollmann, J. (2017): Genetic differentiation within multiple common grassland plants supports seed transfer zones for ecological restoration. - J. Appl. Ecol. 54: 116-126. https://doi. org/10.1111/1365-2664.12636

EC (2010): Commission Directive 2010/60/EU of 30 August 2010 Providing for certain derogations for marketing of fodder plant seed mixtures intended for use in the preservation of the natural environment. - Official Journal of the European Union 228: 1-14.

FCBN (Fédération des Conservatoires Botaniques Nationaux) (2014): Référentiel technique-Associé au règlement d'usage de la marque collective simple végétal local. https://www.plante-etcite.fr/ressource/fiche/333/referentiel technique vegetal_local

Gibson, A. \& Nelson, C. R. (2017): Comparing provisional seed transfer zone strategies for a commonly seeded grass, Pseudoroegneria spicata. - Nat. Area. J. 37: 188-199. https://doi. org $/ 10.3375 / 043.037 .0208$

Giencke, L. M., Denhof, R. C., Kirkman, L. K., Stuber, O. S. \& Brantley, S. T. (2018): Seed sourcing for longleaf pine ground cover restoration: using plant performance to assess seed transfer zones and home-site advantage. - Restor. Ecol. 26: 1127-1136. https://doi.org/10.1111/rec.12673

Hajdú-Moharos, J. \& Hevesi, A. (2002): A kárpát-pannon térség tájtagolódása.- In: Karátson D. (szerk.): Magyarország földje. Kertek 2000 Könyvkiadó, Budapest, pp. 294-306. https://www. arcanum.hu/hu/onlinekiadvanyok/pannon-pannon-enciklopedia-1/magyarorszag-foldje-1D58/ magyarorszag-tajai-2807/a-karpat-pannon-terseg-tajtagolodasa-hajdu-moharos-jozsefhevesiattila-2809/tajbeosztasunk-szempontjai-281B/

Hoban, S. \& Schlarbaum, S. (2014): Optimal sampling of seeds from plant populations for ex-situ conservation of genetic biodiversity, considering realistic population structure. - Biol. Conserv. 177: 90-99. https://doi.org/10.1016/j.biocon.2014.06.014

IPBES (2019): Summary for policymakers of the global assessment report on biodiversity and ecosystem services of the Intergovernmental. Science-Policy Platform on Biodiversity and Ecosystem Services. - Díaz, S., Settele, J., Brondízio, E., Ngo, HT., Guèze, M., Agard, J., Arneth, A., Balvanera, P., Brauman, K., Butchart, S., Chan, K., Garibaldi, LA., Ichii, K., Liu, J., Midgley, GF., Miloslavich, P., Molnár, Zs., Obura, D., Pfaff, A., Polasky, S., Purvis, A., Razzaque, J., Reyers, B., Roy, R., Subramanian, S. M., Shin, YJ., Visseren-Hamakers, I., Willis, K. \& Zayas, C. (eds.). IPBES secretariat, Bonn, $56 \mathrm{p}$.

Kocsis, K. \& Schweitzer, F. (szerk.) (2011): Magyarország térképekben. - MTA Földrajztudományi Kutatóintézet, Budapest. http://www.nemzetiatlasz.hu/2011/Magyarorszag_terkepekben.html

Krautzer, B., Graiss, W. \& Blaschka, A. (2018): Prüfrichtlinie für die Zertifizierung und den Vertrieb von regionalen Wildgräsern und Wildkräutern nach „, Gumpensteiner Herkunftszertifikat” (G-Zert). - Federal Ministry for Sustainability and Tourism, Austria. https://gzert.at/assets/ downloads/G-Zert-Richtlinie-Web.pdf

Ladouceur, E., Jiménez-Alfaro, B., Marin, M., De Vitis, M., Abbandonato, H., Iannetta, P. P., Constantino, B. \& Pritchard, H. W. (2018): Native seed supply and the restoration species pool. Conserv. Lett. 11: e12381. https://doi.org/10.1111/conl.12381 
León-Lobos, P., Bustamante-Sánchez, M. A., Nelson, C. R., Alarcón, D., Hasbún, R., Way, M., Pritchard, H. W. \& Armesto, J. J. (2020): Lack of adequate seed supply is a major bottleneck for effective ecosystem restoration in Chile: Friendly amendment to Bannister et al. (2018). - Restor. Ecol. 28: 277-281. https://doi.org/10.1111/rec.13113

Malaval, S., Lauga, B., Regnault-Roger, C. \& Largier, G. (2010): Combined definition of seed transfer guidelines for ecological restoration in the French Pyrenees. - Appl. Veg. Sci. 13: 113-124. https://doi.org/10.1111/j.1654-109X.2009.01055.X

Massatti, R., Shriver, R. K., Winkler, D. E., Richardson, B. A. \& Bradford, J. B. (2020): Assessment of population genetics and climatic variability can refine climate-informed seed transfer guidelines. - Restor. Ecol. 28: 485-493. https://doi.org/10.1111/rec.13142

Molnár, Cs., Molnár, Zs., Barina, Z., Bauer, N., Biró, M., Bodonczi, L.,Csathó, A., Csiky, J., Deák, J., Fekete, G., Harmos, K., Horváth, A., Isépy, I., Juhász, M., Kállayné Szerényi, J., Király, G., Magos, G., Máté, A., Mesterházy, A., Molnár, A., Nagy, J., Óvári, M., Purger, D., Schmidt, D., Sramkó, G., Szénási, V., Szmorad, F., Szollát, G., Tóth, T., Vidra T. \& Virók, V. (2008): Vegetation-based landscape-regions of Hungary. - Acta. Bot. Hung. 50: 47-58. https://doi.org/10.1556/ ABot.50.2008.Suppl.4

Molnár, Zs., Bartha, S., Seregélyes, T., Illyés, E., Botta-Dukát, Z., Tímár, G., Horváth, F., Révész, A., Kun, A., Bölöni, J., Biró, M., Bodonczi, L., Deák, József Á., Fogarasi, P., Horváth, A., Isépy, I., Karas, L., Kecskés, F., Molnár, Cs., Ortmann-né Ajkai, A. \& Rév, Sz. (2007) A gridbased, satellite-image supported multi-attributed vegetation mapping method (MÉTA). - Folia Geobot. 42: 225-247. https://doi.org/10.1007/BF02806465

Molnár, Zs., Király, G., Fekete, G., Aszalós, R., Barina, Z., Bartha, D., et al. (2018): Növényzet.- In: Kocsis K. (szerk.) Magyarország Nemzeti Atlasza: természeti környezet. MTA CSFK Földrajztudományi Intézet, Budapest, pp. 94-103.

Mucina, L., Bültmann, H., Dierßen, K., Theurillat, J. P., Raus, T., Čarni, A., Šumberová, K., Willner, W., Dengler, J., Gavilán García, R., Chytrý, M., Hájek, M., Di Pietro, R., Iakushenko, D., Pallas, J., Daniëls, F., Bergmeier, E., Santos Guerra, A., Ermakov, N., Valachovič, M., Schaminée, J., Lysenko, T., Didukh, Y. P., Pignatti, S., Rodwell, J. S., Capelo, J., Weber, H. E., Solomeshch, A., Dimopoulos, P., Aguiar, C., Hennekens, S. M. \& Tichý, L. (2016): Vegetation of Europe: hierarchical floristic classification system of vascular plant, bryophyte, lichen, and algal communities. - Appl. Veg. Sci. 19: 3-264. https://doi.org/10.1111/avsc.12257

Pedrini, S. \& Dixon, K. W. (2020) International principles and standards for native seeds in ecological restoration. - Restor. Ecol. 28: S286-S303. https://doi.org/10.1111/rec.13155

Pebesma, E. (2018a): sf: Simple features for R. - R package version 0.6-3. http://cran.rproject.org/ package $=$ sf

Pebesma, E. (2018b): lwgeom: Bindings to selected ,liblwgeom' functions for simple features. - R package version 0.1-4. http://cran.r-project.org/package=lwgeom

Prasse, R., Kunzmann, D. \& Schröder, R. (2010): Entwicklung und praktische Umsetzung naturschutzfachlicher Mindestanforderungen an einen Herkunftsnachweis für gebietseigenes Wildpflanzensaatgut krautiger Pflanzen. Abschlussbericht. - University of Leibniz. Hannover, 166 p. https://www.dbu.de/OPAC/ab/DBU-Abschlussbericht-AZ-23931.pdf

$\mathrm{R}$ Core Team (2018): $R$ : A language and environment for statistical computing. - R Foundation for Statistical Computing, Vienna. www.r-project.org

Retchless, D. P. \& Brewer, C. A. (2016): Guidance for representing uncertainty on global temperature change maps. - Int. J. Climatol. 36: 1143-1159. https://doi.org/10.1002/joc.4408

Somodi, I., Molnár, Zs., Czúcz, B., Bede-Fazekas, Á., Bölöni, J., Pásztor, L., Laborczi, A. \& Zimmermann, N. E. (2017): Implementation and application of multiple potential natural vegetation models - a case study of Hungary. - J. Veg. Sci. 28: 1260-1269. https://doi.org/10.1111/jvs.12564 
Török, K., Horváth, F., Kövendi-Jakó, A., Halassy, M., Bölöni, J. \& Szitár, K. (2019). Meeting Aichi Target 15: Efforts and further needs of ecological restoration in Hungary. - Biol. Conserv. 235: 128-135. https://doi.org/10.1016/j.biocon.2019.04.020

Valkó, O., Tóth, K., Kelemen, A., Miglécz, T., Radócz, S., Sonkoly, J., Tóthmérész, B., Török, P. \& Deák, B. (2018): Cultural heritage and biodiversity conservation-plant introduction and practical restoration on ancient burial mounds. - Nat. Conserv. 24: 65-80. https://doi.org/10.3897/ natureconservation.24.20019

Warnes, G. R., Bolker, B. \& Lumley, T. (2018): gtools: Various R programming tools. - R package version 3.8.1. http://cran.r-project.org/package=gtools

Wickham, H. (2017): tidyverse: Easily install and load the ,Tidyverse'. - R package version 1.2.1. http:// cran.r-project.org/package=tidyverse

Hivatkozott jogszabályok:

VM (2012): 86/2012. (VIII. 15.) VM rendelet a természetes környezet megörzésére szánt takarmánynövény-vetőmagkeverékek kereskedelmi célú begyüjtéséről és forgalmazásáról. Magyar Közlöny, 108: 18490-19498.

Internetes források:

http1: https://www.decadeonrestoration.org

http2: https://www.novenyzetiterkep.hu/potveg_modszer hu

\title{
Vegetation-based survey of seed transfer zones for restoration
}

\author{
Katalin Török ${ }^{1}$, David Cevallos ${ }^{1,2} \&$ Ákos Bede-Fazekas ${ }^{1,3}$ \\ ${ }^{1}$ Centre for Ecological Research, Institute of Ecology and Botany, \\ H-2163 Vácrátót, Alkotmány u. 2-4., Hungary \\ ${ }^{2}$ Eötvös Loránd University, Department of Plant Systematics, Ecology and Theoretical \\ Biology, H-1117 Budapest, Pázmány Péter stny. 1/C, Hungary \\ ${ }^{3}$ Centre for Ecological Research, GINOP Sustainable Ecosystems Group, \\ H-8237 Tihany, Klebelsberg K. u. 3., Hungary \\ E-mail:torok.katalin@ecolres.hu
}

Due to the loss of biodiversity, the concept of ecological restoration has reached the highest political levels. The use of native seeds has to be increased in order to scale up restoration. The use of locally adapted seeds is suggested, and is regulated at EU level. However, in Hungary, "local" is defined based on administrative units. In the present research, we apply multiple potential natural vegetation model and combine it with floristic, vegetation and landscape maps for the delineation of seed transfer zones. We have developed a new methodology to estimate the reliability of the zonation, and found that four or seven zones are better suited to serve as seed transfer zones for restoration. After further fine tuning the zones, the regulation should be changed.

Keywords: ecological restoration, local adaptation, multiple potential natural vegetation, native seed production, phytogeography, regulation of seed transfer 